\title{
AN INVESTIGATION OF THE LEAD AND CADMIUM LEVELS OF BLOOD SERUM AND WOOL OF WHITE KARAMAN SHEEP IN THE VAN REGION (TURKEY)
}

\author{
TUNCER, S. S. \\ Department of Crop and Animal Production, Ozalp Vocational School, Van Yuzuncu Yil \\ University, Van, Turkey \\ (e-mail: selcukseckintuncer@gmail.com; phone: +90-505-839-8794) \\ (Received $17^{\text {th }}$ Oct 2018; accepted $5^{\text {th }}$ Dec 2018)
}

\begin{abstract}
This study was conducted to determine heavy metal (lead $-\mathrm{Pb}$ and cadmium $-\mathrm{Cd}$ ) contamination of White Karaman sheep raised in Centrum (industrial area) and Özalp (rural area) districts of Van province in Turkey. $\mathrm{Pb}$ and $\mathrm{Cd}$ concentrations of blood serum and wool samples were measured with an ICP-OES device at Scientific Research and Implementation Center of Van Yuzuncu Yil University. It was observed that the sheep raised in the Central district of Van had higher levels of $\mathrm{Pb}$ and $\mathrm{Cd}$ in the blood serum and wool than those of the sheep Özalp district $(p<0.001)$. However, $\mathrm{Pb}$ and $\mathrm{Cd}$ levels of the sheep were still below the acceptable limits in both districts of Van province. Present findings revealed that pastures of both districts of Van province were safe with regard to food safety and environmental pollution with heavy metals.
\end{abstract}

Keywords: heavy metal, blood, wool, sheep

\section{Introduction}

Rapid urbanization and industrialization have made heavy metal emissions a global concern even at quite low concentrations for ecosystems (Rouniosi et al., 2018). Especially the heavy metals of lead $(\mathrm{Pb})$ and cadmium $(\mathrm{Cd})$ pose significant health risks for living organisms. Such heavy metals result in disorders in the central nervous system and in the red blood cell synthesis cause weak bone development, pains in muscles, anaemia and deaths ultimately. Therefore, heavy metal pollution levels should be determined and the risks posed on human and animal health should be put forth (Kaptanoğlu et al., 2014).

$\mathrm{Pb}$ and $\mathrm{Cd}$ are abundant metals in environment and they are the most toxic metals (Domingo, 1998; Boğa, 2007). Annually 7600 tons $\mathrm{Cd}$ and 332000 tons $\mathrm{Pb}$ is released to atmosphere through natural phenomena (earthquakes, volcanic eruptions and etc.). On the other hand, 8 times greater $\mathrm{Cd}$ and 6 times greater $\mathrm{Pb}$ is released to atmosphere through anthropogenic activities (urbanization, industrialization and etc.) (Kahvecioğlu et al., 2004). Such a heavy metal pollution has the greatest impacts on plants. Metal pollution not only influence vegetative organs of the plants, but also have significant effects on generative organs of the plants (Zheljazkov and Nielsen, 1996; Okçu et al., 2009).

$\mathrm{Pb}$ exists in nature in organic and inorganic forms. While inorganic form exists in atmosphere in particulate forms, organic $\mathrm{Pb}$ generally contaminates nutrients and drinking water (De Jonghe and Adams, 1982; Karademir and Toker, 1995; Okçu et al., 2009). Therefore, organic forms of $\mathrm{Pb}$ have greater impacts on living organisms. Meat products and plants grown around the industrial zones or city centers may have $\mathrm{Pb}$ levels greater than the normal levels. High-concentration heavy metal intakes of the sheep through pasture plants may pose a high risk of toxicity on animals (Smith et al., 
2010). Lead is not an essential nutrient for soils, generally exist in soils at 15-40 ppm doses and does not pose any health risks on human and plant health under $150 \mathrm{ppm}$ concentration. However, lead concentrations over $300 \mathrm{ppm}$ have potential risks for human health (Dürüst et al., 2004; Öktüren Asri and Sönmez, 2007). Smith et al. (2010) defined $250 \mu \mathrm{g} / \mathrm{l} \mathrm{Pb}$ level as the safe upper limit for blood $\mathrm{Pb}$ levels.

$\mathrm{Cd}$ is relatively rare element and does not exist in pure forms in the nature. It is a significant pollutant since it is toxic at quite low concentrations (Lyons et al., 1996; Okçu et al., 2009). Cd is known with greater toxic impacts on plants (Çatak et al., 2000; Okçu et al., 2009). Accumulation of atmospheric Cd dusts, use of Cd-containing fertilizers and irrigations with wastewater effluents contaminate products consumed by the humans and animals, thus may increase Cd intakes (Jarup and Akesson, 2009; Örün and Yalçın, 2011). Cd levels greater than $3 \mathrm{mg} / \mathrm{kg}$ may have toxic impacts on soils and Cd levels over $1 \mathrm{mg} / \mathrm{kg}$ in plant dry matter may have toxic impacts on plants (Özbek et al., 1995; Öktüren Asri and Sönmez, 2007). Majority of Cd reaching to soils and plants comes from precipitation of Cd-containing atmospheric dust particles. Dust precipitation around the roads with a high traffic intensity may add about $0.2-1.0 \mathrm{mg} / \mathrm{m}^{2}$ Cd to soils annually (Öktüren Asri and Sönmez, 2007). Of the Cd quantities reaching to soils through anthropogenic activities, 54-58\% comes from phosphorus fertilizers, 39$41 \%$ comes from atmospheric storage and $2-5 \%$ comes from sludge and manure treatments (Yost and Miles, 1979).

Turkey with a sheep inventory of 31.507.934 head (TUIK, 2016; Tuncer et al., 2017) is the 7th greatest sheep raiser country of the world (FAO, 2016). The present research site, Van province in Eastern Anatolia Region of Turkey, has the greatest sheep inventory of the country (2.456.493 head) (TUIK, 2016; Tuncer et al., 2017). White Karaman sheep is a race that is widely raised because of very well adapted to the cold and long winter conditions of Eastern Anatolia Region. Therefore, in this study, heavy metal contamination in wool and blood serums of the sheep raised in Van Centrum (industrial area) and Özalp (rural area) districts were investigated and heavy metal contamination was tried to be used as an indicator of food safety and environmental pollution.

\section{Materials and methods}

\section{Research site and sampling}

Van province is among the 5 province of Turkey with the greatest altitude (Eymirli and Kaya, 2016). Of the present research sites (Fig. 1), Central district is located between $38^{\circ} 30^{\prime} 4^{\prime \prime} \mathrm{N}$ and $43^{\circ} 22^{\prime} 22^{\prime \prime}$ E coordinates and Özalp district is located between $38^{\circ} 39^{\prime} 29^{\prime \prime} \mathrm{N}$ and $43^{\circ} 59^{\prime} 21^{\prime \prime}$ E coordinates and the districts have altitudes of $1727 \mathrm{~m}$ and $2075 \mathrm{~m}$, respectively. There is one organized industrial zone in Van Central District. It has 1943 workplaces and 7 small industrial sites. Özalp is one of the smallest districts of Van. In addition, the town of Özalp is industrially backward (Bakır, 2016).

As the animal material of the study, 1-2 years old 15 sheep grazed over the pastures of Central and Özalp districts of Van province in August 2018 were used (a total of 30 sheep). Attention was paid as to have the sheep grazed over the same pastures and as to take blood and wool samples in the same day. Blood samples taken from vena jugularis were placed into anticoagulant $10 \mathrm{ml}$ tubes. About $5 \mathrm{~g}$ wool samples were taken from neck section of the sheep with steel scissors. Wool samples were placed into clean polyethylene bags and preserved till the analyses. Wool samples were taken close to 
skin to eliminate potential differences in heavy metal concentrations in roots and tips (Kurt et al., 2001).

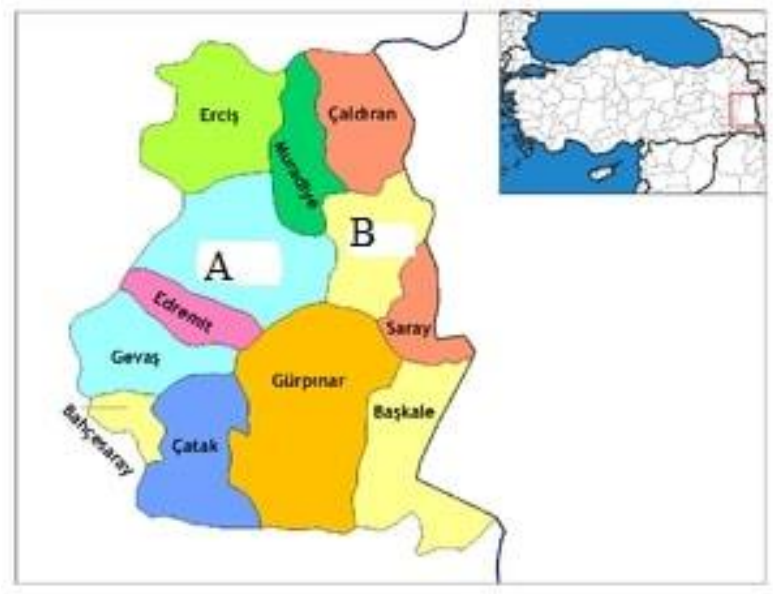

Figure 1. Location of the study areas: A: Van Center, B: Ozalp

\section{Analyses on wool and blood samples}

Blood samples taken from the sheep were placed into anticoagulant tubes with disposable needles. For laboratory analysis, the devices in Van Yuzuncu Yil University Van Health Vocational School and Veterinary Faculty Laboratories were used. Blood samples were centrifuged at $3500 \mathrm{rpm}$ for $15 \mathrm{~min}$ to separate blood serum. Separated serums were transferred to $1.5 \mathrm{ml}$ Eppendorf tubes and preserved at $-20{ }^{\circ} \mathrm{C}$ until the analyses (Karademir, 2007). Wool samples taken from the sheep were washed through $1 \%$ Triton-X 100 solution and rinsed through distilled water. Washed samples were then dried in a sterilizator at $100{ }^{\circ} \mathrm{C}$ for $2 \mathrm{~h}$. Dried samples (100 $\mathrm{mg}$ of them) were placed into tubes, supplemented with $1 \mathrm{ml} \mathrm{1/5}$ nitroperchloric acid mixture and waited for $4 \mathrm{~h}$ for dissolution of wool. Dissolved mixture was completed to $10 \mathrm{ml}$ with distilled water. From this mixture, $1 \mathrm{ml}$ was taken for analysis and supplemented with $2 \mathrm{ml}$ distilled water (Kozat, 2006).

$\mathrm{Pb}$ and $\mathrm{Cd}$ concentrations of blood serum and wool samples were measured with an ICP-OES device at Scientific Research and Implementation Center of Van Yuzuncu Yil University (Alacabey et al., 2017).

\section{Statistical analysis}

GLM sub-procedure of SAS 9.4 (2018) statistical software was used for statistical analyses. One-way ANOVA was applied to mean $\mathrm{Pb}$ and $\mathrm{Cd}$ values of blood serum and wool samples taken from two different regions. Significant means were compared with Duncan's multiple range test. Pearson correlations were calculated between $\mathrm{Pb}$ and $\mathrm{Cd}$ values of serum and wool samples of each region.

\section{Results and discussion}

$\mathrm{Pb}$ and $\mathrm{Cd}$ levels of blood serum and wool samples collected from Akkaraman sheep at pasture season of Van Central and Özalp districts are respectively provided in 
Tables 1 and 2. The greatest $\mathrm{Pb}$ and $\mathrm{Cd}$ values were observed in blood serum and wool samples of the sheep raised in Central district and the differences from the values of the sheep raised in Özalp district were found to be significant $(p<0.01)$, a finding compatible with the literature (Kahvecioğlu et al., 2004; Rouniosi et al., 2018).

Table 1. Pb and Cd values in blood serum of Akkaraman sheep (mean \pm standard error of the mean)

\begin{tabular}{c|c|c|c}
\hline Area & $\mathbf{n}$ & $\mathbf{P b}(\boldsymbol{\mu g} / \mathbf{l})$ & $\mathbf{C d}(\boldsymbol{\mu g} / \mathbf{l})$ \\
\hline Central & 15 & $49.050 \pm 0.004^{\mathrm{a}^{* * *}}$ & $0.375 \pm 0.002^{\mathrm{a}^{* *}}$ \\
Özalp & 15 & $47.025 \pm 0.105^{\mathrm{b}^{* * *}}$ & $0.150 \pm 0.002^{\mathrm{b}^{* *}}$ \\
\hline
\end{tabular}

a, b Different lower cases in the same column represent statistically significant differences

$* * p<0.01$

Table 2. Pb and Cd values of Akkaraman sheep's wool (mean \pm standard error of the mean)

\begin{tabular}{c|c|c|c}
\hline Area & $\mathbf{n}$ & $\mathbf{P b}(\boldsymbol{\mu g} / \mathbf{k g})$ & $\mathbf{C d}(\boldsymbol{\mu g} / \mathbf{k g})$ \\
\hline Central & 15 & $49.375 \pm 0.018^{\mathrm{a}^{* *}}$ & $0.533 \pm 0.068^{\mathrm{a}^{\mathrm{*} *}}$ \\
Özalp & 15 & $47.725 \pm 0.130^{\mathrm{b}^{* *}}$ & $0.218 \pm 0.013^{\mathrm{b}^{* *}}$ \\
\hline
\end{tabular}

${ }^{\mathrm{a}, \mathrm{b}}$ Different lower cases in the same column represent statistically significant differences

$* * p<0.01$

Blood serum $\mathrm{Pb}$ values of the sheep raised in Central and Özalp districts $(49.050 \mu \mathrm{g} / \mathrm{l}$ and $47.025 \mu \mathrm{g} / \mathrm{l})($ Table 1) were quite below the safe limits $(250 \mu \mathrm{g} / \mathrm{l})$. Present values were also quite below the values reported by Villegas et al. (1993) (chronic, $360 \mu \mathrm{g} / \mathrm{l}$ ) and Braun et al. (1997) (acute, $940 \mu \mathrm{g} / \mathrm{l}$ ). As compared to the values of the studies carried out at $\mathrm{Pb}$-contaminated sites, present values were again quite lower than the values reported by Smith et al. (2010) (147 $\mu \mathrm{g} / \mathrm{l})$ and Swarup et al. (2006) (316 $\mu \mathrm{g} / \mathrm{l})$. But, the present values were greater than the values of the same researchers reported for $\mathrm{Pb}$-clean sites (respectively as $26 \mu \mathrm{g} / \mathrm{l}$ and $15 \mu \mathrm{g} / \mathrm{l}$ ). Similar with the present findings, Liu (2003) reported serum $\mathrm{Pb}$ value of the control group as $50 \mu \mathrm{g} / \mathrm{l}$ and Vic1l et al. (2012) reported the same values as between $50 \mu \mathrm{g} / 1$ - $60 \mu \mathrm{g} / \mathrm{l}$. Carrera et al. (2014) reported serum $\mathrm{Pb}$ value of the sheep grazed around the mine sites as $67 \mu \mathrm{g} / 1$ and reported the $\mathrm{Pb}$ value of the rams as $109 \mu \mathrm{g} / 1$ and such values were greater than the present ones. $\mathrm{Pb}$ values of wool samples taken from the sheep raised in Van Central and Özalp districts were found as $49.375 \mu \mathrm{g} / \mathrm{kg}$ and $47.725 \mu \mathrm{g} / \mathrm{kg}$, respectively (Table 2). Present values were quite below the values of Liu (2003) reported for the wool samples of healthy sheep $(1010 \mu \mathrm{g} / \mathrm{kg})$ and the sheep grazed over the $\mathrm{Pb}$-contaminated sites $(3640 \mu \mathrm{g} / \mathrm{kg}$ ); the values of Vicil et al. (2012) reported for the sheep grazed around the mine sites $(2070 \mu \mathrm{g} / \mathrm{kg})$ and the sheep grazed far away from the mine sites $(1130 \mu \mathrm{g} / \mathrm{kg}-1670 \mu \mathrm{g} / \mathrm{kg})$. Present findings revealed that Van Central and Özalp districts could be indicated as clean sites with regard to $\mathrm{Pb}$-contamination.

Present Cd values of blood serums of the sheep raised in Van Central and Özalp districts $(0.375 \mu \mathrm{g} / 1$ and $0.150 \mu \mathrm{g} / \mathrm{l}$, respectively) (Table 1$)$ were quite below the values of Barkouch et al. (2008) reported for the sheep grazed around the mine site $(3900 \mu \mathrm{g} / \mathrm{l})$ and rural $(2900 \mu \mathrm{g} / \mathrm{l})$ sections, the value of Liu (2003) reported for healthy sheep $(20 \mu \mathrm{g} / 1)$. However, present values were greater than the values reported by Vicil et al. 
(2012) $(<0.015 \mu \mathrm{g} / \mathrm{l})$. Cd values of wool samples taken from the sheep raised in Van Central and Özalp districts are provided in Table $2(0.533 \mu \mathrm{g} / \mathrm{kg}$ and $0.218 \mu \mathrm{g} / \mathrm{kg}$, respectively). As compared to the results of the studies carried out over the clean and contaminated sites, present values were lower than the values reported by Liu (2003) $(2030 \mu \mathrm{g} / \mathrm{kg}$ and $370 \mu \mathrm{g} / \mathrm{kg}$, respectively), Barkouch et al. (2008) $(110 \mu \mathrm{g} / \mathrm{kg}$ and $90 \mu \mathrm{g} / \mathrm{kg}$, respectively) and Vicil et al. (2012) (1340 $\mu \mathrm{g} / \mathrm{kg}$ and $450 \mu \mathrm{g} / \mathrm{kg}-3340 \mu \mathrm{g} / \mathrm{kg})$. Present findings revealed that blood serum and wool Cd levels of the sheep grazed over the pastures of Van Central and Özalp districts were at low levels, thus it can be stated that there were no-risk of toxicity.

\section{Conclusions}

$\mathrm{Pb}$ and $\mathrm{Cd}$ levels of blood serum and wool samples were higher in sheep raised in Van Central in industrial area than in the sheep raised in Özalp in rural area $(p<0.001)$. However, $\mathrm{Pb}$ and $\mathrm{Cd}$ values of the sheep in both districts of Van province were below the safe limit values. In brief, toxic levels of heavy metal accumulation ( $\mathrm{Pb}$ and $\mathrm{Cd}$ ) were not encountered in blood serum and wool samples of the sheep. Present findings also revealed that pastures in both districts of Van province were safe with regard to food safety and environmental pollution with heavy metals.

Acknowledgements. The final report of this research project was approved by Van Yuzuncu Yil University Animal Research Local Ethic Committee, decision number 2018/12.

\section{REFERENCES}

[1] Alacabey, İ., Kömürcüoğlu, A. U., Alacabey, N. U., Özdek, U., Kul, A. R., Atasoy, N., Yücel, U. M. (2017): Determination of cobalt (Co) level in hair and serum of gas station workers in Van province. - J Environ Sci Toxicol Food Technol 11(2): 30-32.

[2] Bakır, A. (2016): The analysis of the changes in the amounts of heavy metals in different climate conditions in water and mud examples found in the areas where the stream flows to the lake of Van. - MSc Dissertation, Department of Chemistry, University of Van Yuzuncu Yil, Van, Turkey.

[3] Barkouch, Y., Nocairi, H., Sedki, A., Pineau, A. (2008): Metallic trace elements in blood, wool, kidney and liver of sheep from a mine area of Marrakech-Morocco. Environmental Science 3(1): 15-23.

[4] Boğa, A. (2007): Properties and effects of heavy metals. - Arşiv 16: 218-234.

[5] Braun, U., Pusterla, N., Ossent, P. (1997): Lead poisoning of calves pastured in the target area of a military shooting range. - Schweiz Arch Tierheilkd 139(9): 403-407.

[6] Carrera, J. P., Mateo, R., Estival, J. R. (2018): Lead (Pb) in sheep exposed to mining pollution: Implications for animal and human health. - Ecotoxicology and Environmental Safety 108: 210-216.

[7] Çatak, E., Güler, Ç., Süleyman, T., Orhan, B. (2000): A statistical study on the effects of Cadmium on some tomato and tobacco genotypes. - Journal of Balıkesir University Instute of Science and Technology 2(1): 13-41.

[8] De Jonghe, W. R. A., Adams, F. C. (1982): Biochemical cycling of organic lead compounds. - Ecotoxicology 561-593.

[9] Domingo, J. L. (1998): Developmental toxicity of metal chelating agents. - Reproductive Toxicology 12: 499-510. 
[10] Dürüst, N., Dürüst, Y., Tuğrul, D, Zengin, M. (2004): Heavy metal contents of Pinus radiata trees of İzmit (Turkey). - Asian Journal of Chemistry 16(2): 1129-1134.

[11] Eymirli, E. B., Kaya, M. (2016): Branding of High Altitude Products. - Northeast Anatolia Development Agency, Erzurum, Turkey.

[12] FAO (2016): http://www.faostat.fao.org. - Accessed: 25 October 2016.

[13] Jarup, L., Akesson, A. (2009): Current status of cadmium as an environmental health problem. - Toxicol Appl Pharmacol 238(3): 201-208.

[14] Kahvecioğlu, Ö., Kartal. G., Güven, A., Timur, S. (2004): Environmental effects of metals-I. - Journal of Metallurgical of UCTEA Chamber of Metallurgical Engineers 136: 47-53.

[15] Kaptanoğlu, S., Atasoy, N., Kubilay, Ş., Savran, A., Bakır, A., Yücel, U. F. (2014): Determination of the amount of cadmium in the blood of grazing cattle in the pasture in Van region and investigation of the effects on some specific liver enzymes. $-2^{\text {nd }}$ International Symposium on Environment Morality, Adiyaman, Turkey, pp. 1427-1434.

[16] Karademir, M., Toker, M. C. (1995): Lead accumulation in the grass and plants growing on some of the crossroads of Ankara from exhaust gases. - $2^{\text {nd }}$ National Ecology and Environment Congress, Ankara, Turkey, pp. 699-711.

[17] Karademir, B. (2007): Serum Copper and Zinc Levels of Akkaraman and Tuj Sheep According to Age and Sex Under the Winter Condition. - Kafkas Univ Vet Fak Derg, 13(1): 55-59.

[18] Kozat, S. (2006): Importance, necessity and the effects of deficiencies of trace elements in ruminants. - Journal of Health Sciences of Yuzuncu Yil University 9(2): 58-67.

[19] Kurt, D., Denli, O., Kanay, Z, Güzel, C., Ceylan, K. (2001): An investigation of the copper $(\mathrm{Cu})$, zinc $(\mathrm{Zn})$ and selenium (Se) levels of blood serum and the $\mathrm{Cu}$ and $\mathrm{Zn}$ levels of wool of Akkaraman ewes in the Diyarbakır Region. - Turk J Vet Anim Sci 25: 431436.

[20] Liu, Z. P. (2003): Lead poisoning combined with cadmium in sheep and horses in the vicinity of non-ferrous metal smelters. - The Science of the Total Environment 309(1-3): 117-126.

[21] Lyons, A.M., Tarazona, J. V., Mothersill, C. (1996): The differential effect of cadmium exposure on the growth and survival of primary and established cells from fish and mammals. - Cell Biol. Toxicol. 12: 29-38.

[22] Okçu, M., Tozlu, E., Kumlay, A. M., Pehluvan, M. (2009): The effects of heavy metals on plants. - Alınteri 17: 14-26.

[23] Öktüren Asri, F., Sönmez, S. (2007): The effect of heavy metal toxicity on plant metabolism. - Derim 23(2): 36-45.

[24] Örün, E., Yalçın, S. S. (2011): Lead, mercury, cadmium: Effects on child health and using hair samples in determination of exposure. - Ankara University Journal of Environmental Sciences 3(2): 73-81.

[25] Özbek, H., Kaya, Z., Gök, M. Kaptan, H. (1995): Soil Science. - Çukurova University Faculty of Agriculture, Publication Number: 73, Adana, Turkey.

[26] Rouniosi, N., Monavvari, S. M., Abdoli, M. A., Baghdadi, M., Karbassi, A. R. (2018): Optimization process for the removal of heavy metals from aqueous solution using graphene oxide nanosheets and response surface methodology. - Applied Ecology and Environmental Research 16(5): 6709-6729.

[27] SAS (2018): SAS/STAT Software: Hangen and Enhanced. - SAS Inst Inc, USA.

[28] Smith, K. M., Dagleish, M. P., Abrahams, P. W. (2010): The intake of lead and associated metals by sheep grazing mining-contaminated floodplain pastures in midWales, UK: II. Metal concentrations in blood and wool. - Science of the Total Environment 408: 1035-1042.

[29] Swarup, D., Patra, R. C., Naresh, R., Kumar, P., Shekar, P., Balagangatharathilagar, M. (2006): Lowered blood copper and cobalt contents in goats reared around lead-zinc smelter. - Small Ruminant Research 63(3): 309-313. 
[30] TUIK (2016): Turkish Statistical Institute. Livestock Statistics. https://biruni.tuik.gov.tr/hayvancilikapp/hayvancilik.zul. Accessed: 25 March 2016.

[31] Tuncer, S. S., Sireli, H. D., Dellal, G. (2017): Comparative analysis of various fleece characteristics of Norduz and Zom sheep. - J Anim Plant Sci 27(3): 763-770.

[32] Vicil, S., Erdoğan, S., Uygur, V. (2012): Determination of selected essential and toxic element concentrations in soil, plant, sheep blood and wool samples in Akdağmadeni country. - The Journal of Adana Veterinary Control and Research Institute 2(2): 15-21.

[33] Villegas, N. A., Elena, B. O. D., Raymundo, R. A., Dieck, T. A., Reyes, J. L. (1993): Determination of lead in paired samples of blood and synovial fluid of bovines. - Exp Toxicol Pathol 45(1): 47-49.

[34] Yost, K. J., Miles, L. J. (1979): Environmental health assessment for Cadmium: A systems approach. - J. Environ. Sci. Health 14(4): 285-311.

[35] Zheljazkov, V. D. and Nielsen, N. E. (1996): Effect of heavy metals on peppermint and commint. - Plant and Soil 178(1): 59-66. 